\title{
Pelatihan Penggunaan Aplikasi Komputer Akuntansi Sebagai Media Untuk Meningkatkan Kompetensi Dan Pembelajaran Bagi Guru Dan Siswa Smk N 1 Tapung Pekanbaru
}

\author{
INOVA FITRI SIREGAR
}

\author{
Universitas Lancang Kuning \\ Jln. Yos Sudarso KM 08 Rumbai Telp. (0761) 52581 \\ E-mail : siregar_inovafitri@yahoo.com
}

\begin{abstract}
Activities devotion was conducted in environment vocational high school ( SMK ) $\mathrm{N} 1$ tapung. The participants consisted of teachers and students of vocational high school ( SMK ), which the school not included the curriculum computer application accounting as a subject that must be given in the to school in smk telkom and computer application accounting as one of the to ease presentation of financial report. Devotion is expected to improve understanding in recording, presentation of and reporting a financial report faster, right and accurate, and to make easy in understand presentation of in financial reporting in accordance with the provisions imposed by vocational high school ( SMK ) N 1 Tapung .Through the increase in the competency and the use of computer software application accounting in improve the ability presentation of financial report, expected teachers and students motivated to study and understand the use of computer software application accounting in supporting performance students on while working later on, and do not find it difficult if i can make accountancy softwares anything in the business. A method of execution for the devotion are socialized, simulated and practice how to do recording any transaction provided and in accordance with a standard generally accepted by using software computer application of accounting for students of vocational high school ( SMK ) N 1 Tapung to be taken by approximately 50 participants that consisted of teachers and students. The result is Knowledge and the understanding of participants to software myob accounting evaluated through answer post test that rises significant where $80 \%-90 \%$ already knows myob accounting and he knows benefits, previously only $10 \%$ knew myob accounting and $20 \%$ know of the benefits of myob accounting even with the socialization by means of simulation one case company optimism participants we come to the ability to use application software myob accounting where $80 \%$ said could use application software myob accounting . This was inversely to the answer participants before the socialization where only $30 \%$ said could use application software myob accounting
\end{abstract}

Keywords: Accounting Software

$M Y O B$ Accounting memiliki banyak keunggulan jika dibandingkan dengan aplikasi jenis software akuntansi yang lain yaitu lebih mudah digunakan (user friendly), dengan tampilan menu dan aliran transaksi yang sederhana dan mudah diingat.Aplikasi Komputer Akuntansi mudah dimengerti oleh orang awam yang tidak mempunyai pengetahuan mendalam mengenai komputer dan akuntansi sekalipun tingkat keamanan (security) yang cukup valid untuk semua user karena memiliki fasilitas password yang dapat mengunci keamanan data akuntansi, menampilkan laporan keuangan komparasi (perbandingan) serta menampilkan analisis laporan dalam bentuk grafik

Sekolah Menengah Kejuruan (SMK) N 1 Tapung yang berlokasi di Kecamatan Tapung kabupaten KAmpar merupakan salah satu Sekolah Kejuruan yang ada di kabupaten Kampar yang memiliki lebih dari 250 siswa Akuntansi . dengan banyaknya peminat mahasiswa akuntansi yang bersekolah di SMK N 1 Tapung seharusnya pihak sekolah menyediakan dan memberikan pengetahuan kepada siswa sesuai dengan Ujian Kompetensi (Ujian Kelulusan) yang memadai. 
Sekolah Menengah Kejuruan (SMK) N 1 Tapung menampung lebih dari 250 siswa , khususnya siswa akuntansi. Karna pada kurikulum akuntansi banyak mata pelajaran yang sangat memerlukan labor akuntansi . kurangnya labor akuntansi menyebabkan tidak maksimalnya proses belajar pada siswa. Hal ini dibuktikan dengan menurunnya nilai ujian kompetensi rata-rata sekolah. kemudian selain kurangnya sarana prasarana, kurangnya pengetahuan Guru mata pelajaran untuk menguasai berbagai aplikasi komputer. Hal ini sangat berdampak besar sekali bagi siswa, karena selain siswa akan mengikuti ujian kompetensi, lulusan siswa diharapkan menguasai dan menjadi siswa yang siap pakai pada saat bekerja nantinya.

Permasalahan potensial yang dihadapi mitra adalah :

- Belum adanya pelatihan dan sosialisasi penerapan sistem pencatatan yang terkomputerisasi bagi siswa SMK mengenai Aplikasi Komputer Akuntansi

- MYOB Accounting tidak masuk dalam kurikulum SMK, sehingga penggunaan Aplikasi Komputer Akuntansimasih sesuatu hal yang tidak pernah diaplikasikan oleh siswa SMK

- Kurangnya Sarana dan Prasarana untuk melakukan penerapan sistem pencatatan yang terkomputerisasi.

- Siswa SMK merasa kesulitan jika harus menggunakan sistem pencatatan yang terkomputerisasi. Hal ini dikarenakan tidak adanya pedoman atau buku yang dapat dijadikan referensi

- Pendidik yang berada disekolah kejuruan kurang memiliki sumber daya manusia yang paham dan mengerti mengenai penerapan sistem pencatatan yang terkomputerisasi yaitu dengan Aplikasi Komputer Akuntansi

- Pihak SMK kurang mengetahui bagaimana untuk mendatangkan para praktisi untuk memberikan pelatihan dan sosialisasi mengenai Aplikasi Komputer Akuntansi.

Terkait permasalahan mitra dibutuhkan solusi dalam bagaimana meningkatkan kemampuan dalam penggunaan Aplikasi Komputer Akuntansi sebagai berikut :

- Diharapkan dapat memberi bekal kepada Guru dan Siswa SMK N 1 Tapung sehingga dapat meningkatkan pengetahuan dan pemahaman mengenai penggunaanAplikasi Komputer Akuntansi

- Penggunaan Aplikasi Komputer Akuntansi dengan mudah dan cepat akan memberikan manfaat bagi mereka dalam hal penggunaan Aplikasi Komputer Akuntansi

Berdasarkan uraian di atas, untuk meningkatkan pemahaman guru dan siswa dalam pencatatan, penyajian dan pelaporan keuangan dengan menggunakan software Aplikasi Komputer Akuntansi dengan tingkat pemahaman yang masih kecil dan kurangnya pelatihan dan sangat perlu disosialisasikan, maka memberikan motivasi bagi kami dari dosen Fakultas Ekonomi Universitas Lancang Kuning.

Pelatihan dan sosialisasi yang telah dilaksanakan pada semester gasal mengenai Aplikasi Komputer Akuntansi telah memberikan implementasi yang sangat besar bagi siswa SMK Tapung sehingga dapat memberikan peluang atau kesempatan untuk mempelajari dan memahami aplikasi komputer yang lain, yaitu Aplikasi Komputer Akuntansi. Melalui pelatihan dan sosialisasi kembali yang diberikan dalam meningkatkan kemampuan dalam penggunaan Aplikasi Komputer Akuntansi diharapkan Siswa SMK termotivasi untuk mempelajari dan menggunakan aplikasi akuntansi pada saat bekerja dan menunjang kegiatan bisnis, kemudian tidak merasa kesulitan jika harus menggunakan Aplikasi Komputer Akuntansi dalam kegiatan bisnis. 


\section{METODE}

Kegiatan Pengabdian Kepada Masyarakat dilakukan kepada satu mitra yaitu Siswa SMK N 1 Tapung. Dimana peserta yang ikut berpartisipasi dalam kegiatan pengabdian kepada masyarakat sebanyak 50 orang. Dalam rangka mencapai tujuan yang tercantum di atas, maka pelaksanaan kegiatan dilakukan dengan metode yang sistematis dengan langkahlangkah sebagai berikut :

1. Pelatihan peningkatan pengetahuan tentang definisi dan bentuk dari Laporan Keuangan.

2. Pelatihan peningkatan pengetahuan tentang jenis perusahaan dilihat dari bidang usaha.

3. Diskusi

4. Pelatihan simulasi

5. Pendampingan dan evaluasi hasil

\section{HASIL}

Pengabdian Kepada Masyarakat ini dilakukan oleh Dosen Fakultas Ekonomi Universitas Lancang Kuning. Acara bertempat di Sekolah Menengah Kejuaruan (SMK) Negeri 1 Tapung Kecamatan Tapung dengan judul "Pelatihan Penggunaan Aplikasi Komputer Akuntansi Sebagai Media Untuk Meningkatkan Kompetensi Dan Pembelajaran Bagi Guru Akuntansi Smk N 1 Tapung ". Sebelum kegiatan penyampaian materi mengenai bagaimana cara menyusun laporan keuangan dengan mudah, cepat dan akurat menggunakan software MYOB Accounting, tim dosen pengabdian kepada masyarakat memberikan pre test dengan menyebarkan kuesioner kepada anggota pelatihan yang bertujuan untuk mengetahui sejauh mana pengetahuan dan pemahaman peserta tentang software MYOB Accounting yang sangat membantu dalam mengaplikasikan menyusun laporan keuangan secara mudah, cepat dan akurat
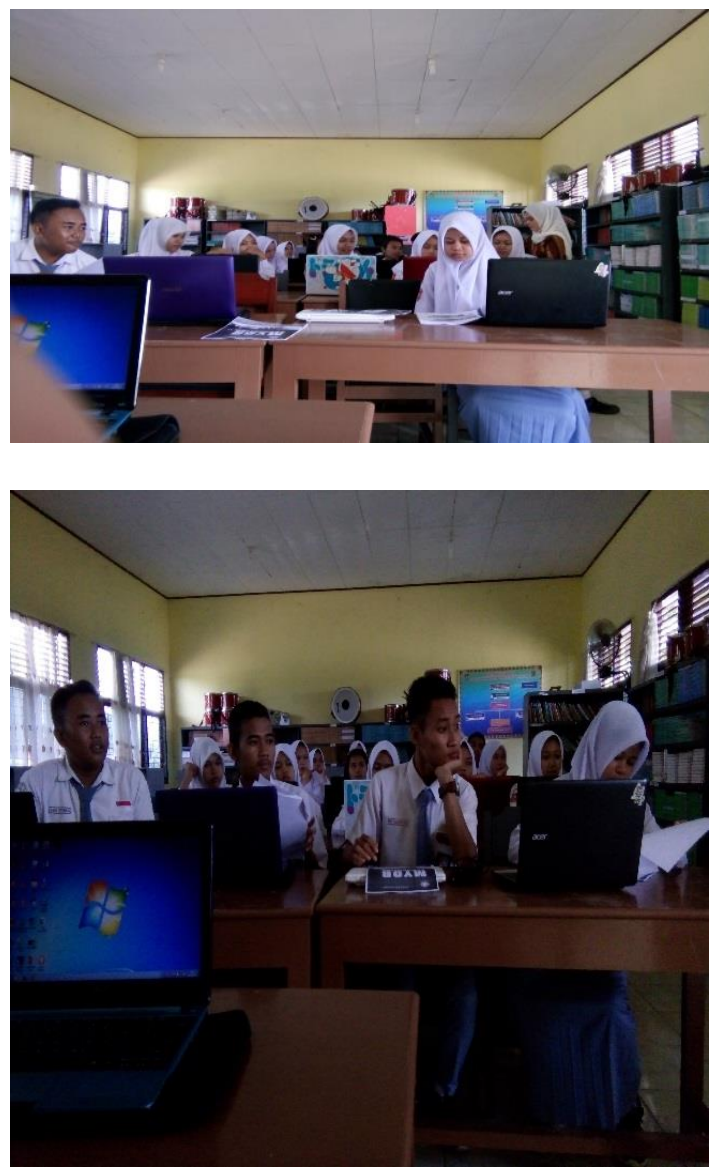

Foto 1 : Tim Pengabdian Kepada Masyarakat memberikan Materi Berkaitan dengan Penggunaan Aplikasi MYOB Accounting

Tabel 1

Rekapitulasi jawaban kuesioner pre dan post test Kegiatan pengabdian kepada masyarakat

\begin{tabular}{|l|l|l|l|}
\hline No & Keterangan & $\begin{array}{l}\text { Pre } \\
\text { Test }\end{array}$ & $\begin{array}{l}\text { Post } \\
\text { Test }\end{array}$ \\
\hline 1 & $\begin{array}{l}\text { Apa yang anda ketahui } \\
\text { tentang program } \\
\text { MYOB Accounting }\end{array}$ & $20 \%$ & $90 \%$ \\
\hline 2 & $\begin{array}{l}\text { Sebutkan paling } \\
\text { sedikit 5 Jenis Modul } \\
\text { yang disajikan dalam } \\
\text { program MYOB } \\
\text { Accounting }\end{array}$ & $\begin{array}{l}\text { Pada Modul Kas dan } \\
\text { Bank, hal apa saja } \\
\text { yang bisa disajikan } \\
\text { pada program MYOB } \\
\text { Accounting }\end{array}$ & $80 \%$ \\
\hline 4 & $\begin{array}{l}\text { Pembayaran piutang } \\
\text { usaha dapat diinput }\end{array}$ & $10 \%$ & $80 \%$ \\
\hline
\end{tabular}




\begin{tabular}{|c|c|c|c|}
\hline No & Keterangan & $\begin{array}{l}\text { Pre } \\
\text { Test }\end{array}$ & $\begin{array}{l}\text { Post } \\
\text { Test }\end{array}$ \\
\hline & $\begin{array}{l}\text { pada modul bagian } \\
\text { mana dari program } \\
\text { MYOB Accounting }\end{array}$ & & \\
\hline 5 & \begin{tabular}{lr}
\multicolumn{2}{l}{ Bagaimana jika } \\
menampin \\
jurnal yang & ada \\
didaftar kas & keluar \\
pada program & MYOB \\
Accounting & \\
\end{tabular} & $10 \%$ & $80 \%$ \\
\hline 6 & $\begin{array}{l}\text { Daftar piutang usaha } \\
\text { mrupakan fitur yang } \\
\text { terdapat di program } \\
\text { MYOB Accounting. } \\
\text { Daftar piutang usaha } \\
\text { dapat kita lihat pada } \\
\text { modul apa? }\end{array}$ & $10 \%$ & $80 \%$ \\
\hline 7 & $\begin{array}{l}\text { Jurnal kas masuk } \\
\text { digunakan } \\
\text { menginput transaksi } \\
\text { penerimaan kas, saldo } \\
\text { rekening kas dan bank } \\
\text { akan bertambah akibat } \\
\text { transaksi tersebut. } \\
\text { Sebutkan langkah- } \\
\text { langkah memasukkan } \\
\text { kas masuk? }\end{array}$ & $10 \%$ & $80 \%$ \\
\hline 8 & $\begin{array}{l}\text { Sebutkan } \\
\text { transaksi apa yang } \\
\text { harus dimasukkan } \\
\text { pada modul kas dan } \\
\text { bank }\end{array}$ & $10 \%$ & $90 \%$ \\
\hline 9 & $\begin{array}{lr}\text { Pada } & \text { modul } \\
\text { persediaan, transaksi } \\
\text { apa saja yang bisa } \\
\text { dimasukkan } & \text { pada } \\
\text { program } & \text { MYOB } \\
\text { Accounting } & \\
\end{array}$ & $10 \%$ & $90 \%$ \\
\hline 10 & $\begin{array}{l}\text { Apa manfaat yang } \\
\text { diperoleh dari program } \\
\text { MYOB Accounting? }\end{array}$ & $30 \%$ & $90 \%$ \\
\hline
\end{tabular}

Sumber : Pengolahan data Excel 2017

Berdasarkan tabel 1 di atas, dapat dilihat bahwa terjadi perubahan yang sangat signifikan dalam menjawab pertanyaan sebelum dan sesudah kegiatan pengabdian kepada masyarakat (pre dan post test). Pengetahuan dan pemahaman peserta dalam penggunaan software MYOB Accounting sebelum dilakukan sosialisasi MYOB Accounting sangat rendah dimana rata-rata hanya $10 \%$ yang menjawab mengetahui MYOB Accounting dan hanya 20\% yang menjawab mengetahui manfaat MYOB Accounting serta hanya $10 \%$ yang menjawab bisa menggunakan aplikasi software MYOB Accounting. Setelah dilakukan sosialisasi software MYOB Accounting pengetahuan dan pemahaman peserta dalam penggunaan MYOB Accounting meningkat sangat signifikan. Hal ini terlihat bahwa rata-rata hasil jawaban sebesar 80\%-90\%.

\section{PEMBAHASAN}

Pengetahuan dan pemahaman peserta terhadap software MYOB Accounting dievaluasi melalui jawaban post test yang meningkat signifikan dimana $80 \%-90 \%$ sudah mengetahui MYOB Accounting dan mengetahui manfaatnya, sebelumnya hanya $10 \%$ yang mengetahui MYOB Accounting dan 20\% yang mengetahui manfaat MYOB Accounting Bahkan dengan sosialisasi yang dilakukan dengan cara simulasi satu kasus perusahaan maka terjadi optimisme peserta terhadap kemampuan menggunakan aplikasi software Myob Accounting dimana $80 \%$ menyatakan bisa menggunakan aplikasi software MYOB Accounting. Hal ini berbanding terbalik dengan jawaban peserta sebelum dilakukan sosialisasi dimana hanya $30 \%$ yang menyatakan bisa menggunakan aplikasi software MYOB Accounting.

Berdasarkan evaluasi pelaksanaan kegiatan dapat diidentifikasi faktor pendukung dalam pelaksanaan program pengabdian kepada masyarakat adalah : Adanya kerjasama yang baik antara tim pengabdian kepada masyarakat dengan peserta siswa-siswa SMK dan Para Guru Mata Pelajaran Komputer Akuntansi SMK Negeri 1 Tapung. Adanya kerjasama yang baik antara tim pengabdian kepada masyarakat dengan Kepala Sekolah SMK Negeri 1 Tapung beserta jajarannya dalam mensupport terselenggaranya kegiatan ini dalam bentuk pemberian fasilitas ruangan, 
proyektor, menghadirkan peserta yang akan diberikan sosialisasi MYOB Accounting serta kesediaan Kepala Sekolah SMK Negeri 1 Tapung memberikan kata sambutan sekaligus membuka kegiatan pengabdian kepada masyarakat tersebut. Partisipasi aktif dan antusiasme yang tinggi dari peserta siswa-siswa SMK dan Para Guru Mata Pelajaran Komputer Akuntansi SMK Negeri 1 Tapung dalam mengikuti seluruh rangkaian kegiatan.

\section{SIMPULAN}

Kegiatan pengabdian kepada masyarakat ini dilaksanakan di Kelas SMK Negeri 1 Tapung dengan judul "Pelatihan Penggunaan Aplikasi Komputer Akuntansi Sebagai Media Untuk Meningkatkan Kompetensi Dan Pembelajaran Bagi Guru Akuntansi SMK N 1 Tapung" yang diadakan pada hari Sabtu, 20 Februari 2017 yang dihadiri oleh 30 Peserta, terdiri dari Siswa SMK dan Para Guru Mata Pelajaran Komputer Akuntansi SMK N 1 Tapung Provinsi Riau"

Sesuai dengan tujuan kegiatan pengabdian kepada masyarakat yang telah dilakukan, dapat diambil beberapa kesimpulan sebagai berikut : Meningkatkan peran serta Fakultas Ekonomi Universitas Lancang Kuning dalam ikut membantu sekolah sekolah menengah kejuruan yang baru berdiri dengan cara melakukan pembinaan terhadap SMK N 1 Tapung melalui kegiatan pengabdian kepada masyarakat dalam bentuk sosialisasi dan peningkatan penggunaan aplikasi software MYOB Accounting untuk pelaporan keuangan bagi Siswa SMK dan Para Guru Mata Pelajaran Komputer Akuntansi SMK N 1 Tapung Provinsi Riau berjalan dengan baik dan lancar sesuai dengan yang diharapkan. Siswa SMK dan Para Guru Mata Pelajaran Komputer Akuntansi SMK N 1 Tapung Provinsi Riau telah memiliki pengetahuan dan pemahaman akan pentingnya penggunaan aplikasi software MYOB Accounting dalam pelaporan keuangan yang mudah, cepat dan akurat. Pada pelaksanaan sosialisai, peserta diberikan kuesioner dalam bentuk pre dan post test, hasil dari pre dan post test tersebut menunjukkan perubahan yang sangat signifikan terhadap pengetahuan dan pemahaman peserta terhadap software MYOB Accounting

Berdasarkan kesimpulan di atas, maka dapat kami sarankan hal-hal sebagai berikut: Perlu adanya kegiatan pelatihan penggunaan software MYOB Accounting secara bertahap dan berkelanjutan sebagai lanjutan dari kegiatan sosialisasi ini, agar siswa-siswa SMK tidak hanya sekedar memiliki pengetahuan dan pemahaman terhadap software MYOB Accounting akan tetapi mereka benar-benar menggunakan software ini dalam membantu pelaporan keuangan dengan mudah, cepat dan akurat. Perlu adanya pendampingan dari instansi terkait.

\section{DAFTAR RUJUKAN}

Ali Imran. 2009. 17 Jurus MempelajariAplikasi Komputer Akuntansi, Edisi Kesatu. Yogyakarta: Penerbit Andi

Hendra Wijaya, 2015. Excel Akuntansi, Jakarta : Penerbit PT Elex Media Komputindo

Reeve. 2005. "Accounting : Pengantar Akuntansi". Buku satu. Edisi dua puluh satu. Jakarta; Salemba Empat

Siregar. Inova Fitri, 2017. MYOB Accounting, Edisi Kesatu. Pekanbaru : Penerbit Unilak Press

Soemarso S. R. 2004. "Akuntansi Suatu Pengantar". Buku satu. Edisi lima. Jakata: Salemba Empat

Tanjung, Yulia, Haryani.2009. Analisis Penerapan PSAK No.1 Tentang Penyajian Laporan Keuangan Pada PT.PLN (Persero) Area 
232 Pelatihan Penggunaan Aplikasi Komputer Akuntansi Sebagai Media Untuk Meningkatkan Kompetensi Dan Pembelajaran Bagi Guru Dan Siswa Smk N 1 Tapung Pekanbaru (Inova Fitri Siregar)

Padang. Jurnal Ekonomi dan kewirausahaan.

Yenti, Hidayah.2010. Pelatihan Penyusunan Laporan Keuangan Koperasi bagi kelompok tani wanita "Panen Raya" di Kanagarian Tarok Kecamatan Baso Kabupaten Agam. Artikel Kegiatan Pengabdian Kepada Masyarakat. 